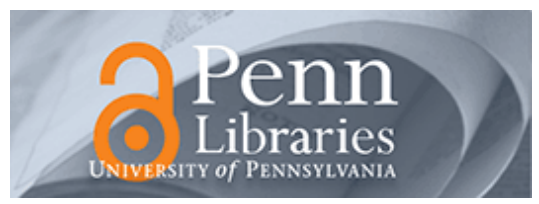

University of Pennsylvania

ScholarlyCommons

Accounting Papers

Wharton Faculty Research

$9-2013$

\title{
The Financial Reporting of Fair Value Based on Managerial Inputs Versus Market Inputs: Evidence From Mortgage Servicing Rights
}

Jennifer M. Altamuro

University of Pennsylvania

Haiwen Zhang

Follow this and additional works at: https://repository.upenn.edu/accounting_papers

Part of the Accounting Commons

\section{Recommended Citation}

Altamuro, J. M., \& Zhang, H. (2013). The Financial Reporting of Fair Value Based on Managerial Inputs Versus Market Inputs: Evidence From Mortgage Servicing Rights. Review of Accounting Studies, 18 (3), 833-858. http://dx.doi.org/10.1007/s11142-013-9234-y

This paper is posted at ScholarlyCommons. https://repository.upenn.edu/accounting_papers/4

For more information, please contact repository@pobox.upenn.edu. 


\title{
The Financial Reporting of Fair Value Based on Managerial Inputs Versus Market Inputs: Evidence From Mortgage Servicing Rights
}

\begin{abstract}
This research examines whether the fair value of mortgage servicing rights (MSRs) based on managerial inputs (Level 3) better reflects the cash flow and risk characteristics of the underlying assets than the fair value of MSRs based on market inputs (Level 2). Using mortgage servicing fees as a proxy for the underlying cash flows, we find that the valuation multiples for MSRs based on Level 3 inputs are more positively associated with the persistence of future servicing fees compared with the fair value of MSRs based on Level 2 inputs. We also document that only the valuation multiples based on Level 3 fair values are negatively associated with proxies for risk factors. Our results suggest that, although unobservable inputs are subject to managerial discretions, managers can generate higher quality fair value estimates than market inputs due to their information advantage, especially when the market for the underlying asset is inactive.
\end{abstract}

\section{Keywords}

mortgage servicing rights, fair value, market inputs, managerial inputs, FAS 157

Disciplines

Accounting 


\title{
The Financial Reporting of Fair Value Based on \\ Managerial Inputs versus Market Inputs: Evidence from Mortgage Servicing Rights
}

\author{
Jennifer Altamuro \\ Accounting and MIS department \\ The Ohio State University \\ Altamuro.1@osu.edu \\ 614-688-8679 \\ Haiwen (Helen) Zhang* \\ Accounting and MIS department \\ The Ohio State University \\ Zhang.614@osu.edu \\ 614-292-6547
}

* Corresponding author.

The authors thank Patricia Dechow (editor), Cathy Shakespeare, Bradley Hendricks, an anonymous referee, Kris Allee, Anne Beatty, Gopal Krishnan, Heibatollah Sami, Andrew Van Buskirk, Dan Russomanno and the seminar participants at the 2012 RAST Conference, The Ohio State University, Lehigh University, Pennsylvania State University and the 2011 American Accounting Association Annual Meeting for their helpful comments and suggestions. We are grateful for the excellent research assistance provided by Dun Liu, Michelle Fan and Austin Sudbury. We also thank Urum Urumoglu of Balance Sheet Solutions, LLC and Eric Nokken of Wilary Winn, Inc for sharing their knowledge of the mortgage servicing market and related accounting issues with us. 


\begin{abstract}
This research studies one specific financial instrument - Mortgage Servicing Rights (MSRs) and examines whether the fair value of MSRs based on managerial inputs (Level 3 ) has financial reporting characteristics that differ from the fair value of MSRs based on market inputs (Level 2). Since fair value represents discounted future cash flows, we use future mortgage servicing fees as a proxy for future cash flows and measure whether the fair value of MSRs reflects the persistence of future servicing fees. We find that the fair value of MSRs based on managerial inputs (Level 3) better reflects the persistence of future servicing fees compared with the fair value of MSRs based on market inputs (Level 2). We also document that Level 3 fair values have a stronger association with proxies for default risk and prepayment risk. Consistent with conjectures made by Ryan (2008) and Laux and Leuz (2009), our results suggest that, although unobservable inputs are subject to managerial discretions, managers have the potential to generate higher quality fair value estimates than market inputs due to their information advantage, especially when the market for the underlying asset is inactive.
\end{abstract}




\section{Introduction}

Improving our understanding of the financial reporting characteristics of fair value measurements has long been an important issue for accounting standard setters, academics, and professionals. Statement of Financial Accounting Standard (FAS) 157 "Fair Value Measurements" provides implementation guidance for the measurements of assets and liabilities at fair value through a hierarchical framework and proposes that "the fair value hierarchy gives the highest priority to quoted prices (unadjusted) in active market for identical assets or liabilities (Level 1) and the lowest priority to unobservable inputs (Level 3)". However, if the market for the underlying asset is inactive, FAS 157 allows managers to use their discretion and choose either to use models derived from managerial inputs (level 3) or market inputs (level 2) to value the assets and liabilities. Laux and Leuz (2009) note that the flexibility to use discretion in fair value accounting choices may be particularly relevant during periods of financial crisis. Ryan (2008) further contends that,

"While Level 2 inputs generally are preferred to Level 3 inputs, FAS 157 does not necessarily require firms to use Level 2 inputs over Level 3 inputs. Firms should use the assumptions that market participants would use in pricing the asset or liability. When markets are illiquid, firms can make the argument that available Level 2 inputs are of such low quality that market participants would use Level 3 inputs instead."1

Although managers may have an information advantage over an inactive market and incorporate private information through managerial input models, they also have incentives to impose biased model assumptions during the valuation process. In this paper, we examine whether fair values based on managerial inputs are more useful for

\footnotetext{
${ }^{1}$ In light of the financial crisis that began in 2007, the Financial Accounting Standards Board (FASB) released staff position papers FAS 157-3 and 157-4, recognizing that additional guidance is required for the adoption of fair value accounting during periods when a market is not active, or the transactions associated with an asset or liability are not orderly. Consistent with the conjectures in Ryan (2008), the FASB acknowledged that "multiple valuation techniques" might be the most appropriate way to determine fair values, and that the determination of prices and market conditions used to generate prices "depends on the facts and circumstances and requires the use of significant judgment."
} 
decision making than fair values based on market inputs, particularly when the market for the underlying assets or liabilities is inactive.

While most academic research ${ }^{2}$ and media attention focuses on aggregate values of assets and liabilities measures at fair value, managers make valuation and accounting decisions at the transaction/instrument level. Consequently, it is difficult to disentangle the impact of the aggregation of heterogeneous instruments when trying to reach conclusions about the decision usefulness of fair values using market inputs or managerial inputs. Additionally, decision usefulness is often operationalized as the market's response to fair value measurements. Market responses to fair value measurements can be the result of the characteristics of the instrument, or the accounting and valuation choices made by management, which can also be difficult to isolate and identify.

To address our research question, we examine one specific financial instrument, Mortgage Servicing Rights (MSRs), and compare the financial reporting characteristics of MSRs classified as Level 2 assets with those of Level 3 assets. Mortgage servicing is the act of keeping a mortgage loan current, including collecting current and overdue payments, forwarding payments to the actual mortgage holder, and making any property tax and insurance payments related to the mortgaged property. Servicing may be performed by the originator of the mortgage, or the original lender may sell the right to service, an MSR, to another lender. The servicing activity is a source of income and cash flows for the service provider and the estimation of these future cash flows will ideally be reflected in the value of the MSR at the balance sheet date. Current accounting rules require that MSRs are initially measured at fair value and subsequently measured at either the lower of amortized cost or market, or fair value. While the size of the MSR market is

\footnotetext{
${ }^{2}$ See section 2 for detailed literature review.
} 
non-trivial (exceeding $\$ 60$ billion in 2009), the market is not an active one, with very few trades each quarter. Because of the infrequent trading, virtually all MSR fair values are determined using a DCF model. Some models are derived using only market-observable inputs, while others incorporate manager's private information and other unobservable data. Consequently, mortgage servicing rights are classified as either Level 2 or Level 3 fair value assets under the SFAS 157 hierarchy.

Based on the information provided in banks' regulatory filings and their 10-Q and 10K reports from 2008 to 2011 , we collect the fair value of the MSRs for 82 bank- holding companies (978 bank-quarters) and identify the servicing revenue generated each quarter from these MSRs. ${ }^{3}$ We start the sample period from 2008 because FAS 157 is effective for all fiscal periods beginning after November 15, 2007. Most of the bank-holding companies in our sample (62 out of 82 banks) always classify their mortgage servicing rights as Level 3 assets over the entire four-year period, indicating that these banks use managerial inputs to estimate the fair value of MSRs. However, we also find that 20 banks classify their MSRs as Level 2 assets for at least one quarter, indicating these banks contend to rely solely on market-observable inputs for MSR valuation ${ }^{4}$.

Before comparing the quality of the Level 2 fair value with that of the Level 3 fair value, we first examine the determinants of Level 2 versus Level 3 classification for MSRs in a given quarter. We document that the choice to account for MSRs as Level 3 is positively associated with bank-level foreclosure activity of the servicing portfolios, and state-wide subprime lending activity. The Level 3 choice is also negatively associated with changes in state-level housing prices. Since banks, especially smaller regional banks, tend to service loans originated in the local market, these results suggest that banks that choose

\footnotetext{
${ }^{3}$ Although our sample is small, these 82 banks comprise over $85 \%$ of the U.S. market for mortgage servicing rights.

${ }^{4}$ Thirteen banks always classify their MSR assets as Level 2 for the entire four-year period.
} 
Level 3 fair value have riskier underlying mortgage servicing portfolios. ${ }^{5} \mathrm{We}$ also find that Level 3 classification is more likely to be chosen by larger banks with Big Four auditors, and banks that choose to value their MSRs on an ongoing fair value basis. We do not find any association between lower accounting quality and the Level 2 versus Level 3 classification choice.

The fair value of the MSRs is calculated as the sum of the discounted expected future cash flows, where the majority of the future cash flows are based on a percentage of the outstanding principal balances. Thus, the most important risks associated with MSRs are mortgage defaults and prepayment/refinancing activity (Brown et al, 1992, Lin et al, 2006). Since both risk factors negatively affect the persistence of the underlying cash flows, we also use the persistence of the servicing fees as a summary measure of the riskiness of the underlying mortgage servicing rights. The prices of the mortgage servicing assets are usually quoted as a multiple of its contractual servicing revenue. Similar to other financial instruments, the valuation multiple is higher when the underlying assets are less risky. Thus, we test our research question by examining which MSR fair value (Level 2 or Level 3) better reflects the risk characteristics of the underlying servicing portfolio, which are proxied by the persistence of the servicing fees, the foreclosure risk of the servicing portfolio, and the state-level refinancing risk. Based on the results from our choice model, we control for significant differences between the Level 2 and Level 3 samples. Level 2 MSR banks are much smaller than Level 3 MSR banks, virtually all Level 2 MSR banks (except for one) value their MSR assets on a lower of cost or market basis and Level 2 banks appear to conduct business in areas with

\footnotetext{
${ }^{5}$ Fifty-two percent of our sample firms disclose sources of changes in mortgage servicing rights during a given year. Based on the available disclosures, more than $95 \%$ of the servicing rights are derived from loans originated but subsequently sold with servicing rights retained.
} 
a more stable housing market. Therefore, in addition to comparing the Level 2 MSR banks with the full sample of the Level 3 MSR banks, we also compare Level 2 MSR banks with Level 3 MSR banks that are of similar size, that use the lower of cost or market valuation option, and that are in areas with similar housing markets. Consistent with the results from the Probit model, we find the persistence of servicing fee revenues is higher for Level 2 MSRs than Level 3 MSRs on average. However, the difference in the servicing fee persistence is not significant after matching Level 2 banks with Level 3 banks on the accounting choices, size, and regional housing-market conditions, suggesting the above factors successfully control for the riskiness of the servicing portfolios.

Our main test results suggest that Level 3 fair values better reflect the risk characteristics of the underlying servicing portfolios. Specifically, we find that the MSR valuation multiple based on Level 3 fair value is positively associated with persistence of the servicing fees and negatively associated with proxies for default risk and prepayment risk. We do not find the valuation multiple based on Level 2 fair value reflects the risk characteristics of the underlying servicing portfolios. We also find that the above results hold for both recession and post-recession period.

These results suggest that, when an asset is infrequently traded, fair values based on market inputs may not reflect the underlying cash flows. Instead, fair values based on managerial inputs incorporate firm-specific information more effectively, and better reflect the underlying economic characteristics of the assets/liabilities. We believe these findings are particularly relevant to the ongoing debate about the role of fair value accounting in financial reporting and valuation. A study of a particular asset class such as MSRs provides the benefit of examining a single type of asset rather than looking at an 
aggregation of assets that may be subject to different valuation models or techniques. Unlike marketable securities which generate cash flows upon sale or the receipt of interest or dividends, the MSR is not a "passive" asset; the servicing is an activity performed by the banks which generates cash flows that are relatively more predictable than those related to other assets. Our findings suggest that the quality of the fair value inputs does differ across the levels of the hierarchy. However, contrary to some arguments contending that fair values based on managerial inputs are less informative and more biased than fair values based on market inputs, we provide evidence that there are instances where the unobserved Level 3 valuation inputs are more reflective of the economic attributes of the underlying assets than the observable Level 2 inputs, consistent with the conjectures in Ryan (2008). This distinction appears to be particularly relevant when investors have incomplete information about the economic attributes of the underlying assets or related assets.

The remainder of this paper continues as follows; section 2 provides some background information about fair value accounting and mortgage servicing rights. Section 3 describes our sample and the research methods. We provide the results of our analyses in Section 4 and conclude in section 5.

\section{Background and Research Question}

\subsection{Fair Value Accounting and SFAS 157}

Much of the debate surrounding the use of fair values has been centered on the perceived reliability of these measures. Muller (1998) examines acquired brand names, measured at fair values, by U.K. firms and provides evidence that reliability may be compromised by managers trying to meet certain contracting incentives. Aboody et al (1998) examine the relationship between revaluations of fixed assets in the UK and 
changes in future performance and conclude that a significant positive association is indicative of the reliability of the revaluation amounts. Following a suggestion by Sloan (1998) that "ex-post realizations [...] should correspond more closely to the attributes being estimated," Dietrich et al (2001) document that on average, fair value estimates are lower than actual selling prices, but are more accurate than historical costs for UK investment properties. They find evidence that managers will exert opportunistic discretion over reported fair value estimates, but that the reliability of these estimates is improved in the presence of external monitors. However, Cotter and Richardson (2002) document that in a sample of Australian asset revaluations, firms were more likely to engage the board of directors than an outside appraiser when investment and intangible assets were subject to revaluation, consistent with insiders having greater expertise related to firm-specific assets. They also did not document a difference in reliability for these types of assets between independent appraisers and internal appraisers. While these studies provide evidence that current values provided some information to the market, they also provide some evidence consistent with the concerns of those that oppose the use of fair values, mainly that they are more likely to be subjected to opportunistic choices by managers, especially when they are internally generated measures.

In conjunction with the growing use of fair values in financial statements, the Financial Accounting Standards Board reexamined the fundamental characteristics of financial reporting. In Concept Statement 8 - The Conceptual Framework (CON8), the FASB contends that "If financial information is to be useful, it must be relevant and faithfully represents what it purports to represent." $\mathrm{CON} 8$ addresses the change from reliability to faithful representation by commenting on the different interpretations of reliability made by practitioners and financial statement users. Specifically, the Board 
noted that "In particular, many respondents' descriptions of reliability more closely resembled the Board's notion of verifiability than its notion of reliability. The Board even allows for the possibility that financial information can still be a faithful representation even if the secondary quality of verifiability is not met. ${ }^{6}$

Even though the conceptual framework has changed to a requirement of faithful representation, the current standards that guide the reporting of fair values were written under the "reliability = verifiability" regime. In an effort to improve the transparency and comparability of assets and liabilities reported at fair value, the Financial Accounting Standards Board issued SFAS 157 - "Fair Value Measurements" effective for fiscal years beginning after November 15, 2007. The framework imposed by SFAS 157 presents a hierarchy of fair value measurements that distinguishes between observable and unobservable inputs and assumptions about the value of an asset or liability, with the position that those fair values will become progressively less reliable/verifiable as inputs become less transparent to the market. Level 1 measurements are the most reliable and visible to financial statement users, as they are based on quoted prices from active, liquid markets for the same assets. Level 2 measurements are still considered to be marked-tomarket prices or fair value models based on market inputs, but these markets are not perceived to be as reliable as Level 1 markets either due to market illiquidity or differences in the underlying assets because Level 2 pricing is based on observable prices in an active market for similar assets, or prices in an inactive market for identical assets. Finally, Level 3 measurements are based on unobservable inputs that reflect

\footnotetext{
${ }^{6}$ CON8 Paragraph BC3.10 - The Board does not agree that the distinction is arbitrary. Financial information without the two fundamental qualitative characteristics of relevance and faithful representation is not useful, and it cannot be made useful by being more comparable, verifiable, timely, or understandable. However, financial information that is relevant and faithfully represented may still be useful even if it does not have any of the enhancing qualitative characteristics.
} 
managerial assumptions about the characteristics of a market for these assets or liabilities if such a market existed. These measurements are often referred to as marked-to-model, and require more extensive disclosures in the financial statements than Level 1 or Level 2 prices. In this context, it appears that the SFAS 157 hierarchy system is based on verifiability, which indicates that managerial discretion may reduce the quality of Level 3 fair values.

Recognizing the potential weakness of Level 2 fair values, especially during the economic crisis, FAS 157 does allow managers to make the argument that available Level 2 inputs are of such low quality that Level 3 fair values are preferable if the market for the underlying assets is illiquid. As noted in Laux and Leuz (2009), FAS 157-3 emphasizes that while managers may use models and unobservable inputs, they must incorporate the information contained in market prices, and also hold that illiquid markets may not be a sufficient reason to deviate from the use of market prices. As contended in Laux and Leuz (2010), "The fundamental difficulty here is that managers have an information advantage over auditors and regulators, which in turn makes it difficult to write and enforce accounting standards that both provide flexibility when it is needed and also constrain managers' behavior where flexibility can be used opportunistically."

The majority of the academic research related to SFAS 157 has focused on the value relevance for stock prices of information reported in the hierarchical framework. In their review paper, Maines and Wahlen (2006) cite work by Barth (1991) and Choi (1997) regarding the relationship between post-retirement obligations and share prices. Maines and Wahlen (2006) then make inferences about investors' reactions to the proposed SFAS 157 standard and suggest that investors are likely to decrease the weight 
placed on "less reliable" Level 3 fair value measurements in their equity pricing decisions. Maines and Wahlen (2006) also suggest that future research should focus on how accounting value reflects the underlying cash flows as a potential measure of reliability. Riedl and Serafeim (2009) derive portfolios of assets based on their levels classifications and contend that Level 3 assets have higher implied betas and lead to larger bid-ask spreads relative to Level 1 and Level 2 assets, consistent with the argument that Level 3 induces a greater amount of information asymmetry. Goh et al (2009) examine investor reliance on the fair value estimates of assets reported by banks. The authors find lower pricing for marked-to-model assets than marked-to-market. Song et al (2010) document that the value relevance of Level 1 fair value net assets on stock prices is greater than the value relevance of Level 2 and Level 3 net assets, but the value relevance of these less reliable measures is greater for firms with stronger corporate governance. Kolev (2009) finds evidence that the mark to model estimates are generally less value relevant than those based on unadjusted market prices, with the gap more pronounced for firms with lower equity capital and fewer financial experts on the audit committee. Overall, these studies find evidence supporting the conjecture that the levels classification of fair value measurements has an impact on the equity valuation of the firm. Finally, Botosan et al (2011) examine the factors influencing banks' tendency to use Level 3 inputs for their MBSNA available for sale securities and find both market liquidity and valuation resources affect the use of Level 3 inputs. Different from Botosan et al. (2001), this paper primarily focuses on whether L3 fair value better represents the economic characteristics of the underlying assets.

\subsection{Mortgage Servicing Rights}

Mortgages are serviced when banks engage in activities that keep mortgage loans 
current, including collecting payments of principal and interest, forwarding payments to the mortgage holder if the holder is not the servicer, and making all necessary tax and insurance payments on the mortgaged property. The right to service the mortgage may be retained by the original lender, or may be sold to another party. Consequently, the servicing right is an asset that can be valued separately from the related mortgage loan. Typically, for conventional servicing, the servicing fee is about 25 basis points of the balance of the underlying loan [Aldrich et al (2001)] $]^{7}$. An MSR asset is recognized if the benefit associated with servicing exceeds "adequate compensation," defined as the amount needed to fairly compensate another servicer. ${ }^{8}$ The passage of SFAS 122 in 1996 standardized the accounting treatment for both originated and purchased MSRs, requiring capitalization at origination/purchase, then amortization over the life of the loan. SFAS 140 applied the principle of lower of cost or market to MSRs, but the largest change to MSR accounting occurred with the passage of SFAS 156 "Accounting for Servicing of Financial Assets." SFAS 156 provided a "fair value option" to banks with MSRs. Initial measurement of the MSR is at fair value, and subsequent measurement may continue at fair value, or at a lower of amortized cost or market. If fair value measurement is chosen for an MSR, the choice is irrevocable, however MSRs measured at lower of amortized cost or market can make a one-time election to use fair values. Banks that choose the fair value option for their MSRs disclose whether the MSRs are Level 2 or Level 3 "recurring" fair value assets on a quarterly basis. Banks that choose

\footnotetext{
${ }^{7}$ Banks that intend to originate and service mortgages, but do not intend to hold the mortgage portfolio usually have the intention of selling their conforming loans (those under \$417K) to Freddie Mac or Fannie Mae. Twenty-five basis points are the industry standard for conforming loan portfolios sold to Freddie/Fannie.

8 "Adequate Compensation" is determined by the market level costs of servicing plus a normal profit margin. Since the majority of the servicing costs incurred are upfront investments in resources required to engage in the servicing activities, "Adequate Compensation" is often manifested in the form of fixed costs per loan. Therefore, servicing rights may generate a net liability when the outstanding principal balance drops to a certain level (usually $\$ 20,000$ to $\$ 30,000$ ). Banks only report a net asset or liability amount for all servicing portfolios in the regulatory report. In our sample, all banks report net MSR assets across all quarters.
} 
the lower of cost or market for their MSRs disclose whether MSRs are Level 2 or Level 3 "non-recurring" fair value assets on a quarterly basis.

The use of fair values to measure MSRs is not without controversy. Emrick (2006) expressed concerns that SFAS 156 would decrease the usefulness of financial reports because reliability and comparability would be compromised as a result of the fair value measurements. However, they also noted that the fair value option provides symmetrical treatment for MSRs and hedges, reducing the volatility in earnings that occurs in hedge relationships that do not qualify for hedge accounting. SFAS 157 provided additional guidance for firms that were using fair values to determine the value of MSRs on their balance sheet.

The market for MSRs is substantial (over $\$ 60$ billion at the end of 2009) and highly concentrated, with the top ten servicers holding $60 \%$ of the market share (Urumoglu [2010]). However, trades within this market are very scarce. Based on the infrequent trading, MSRs are classified by mortgage servicers as either Level 2 or Level 3 assets. Those that determine the MSR value with a Level 2 classification could (1) use a DCF model based on inputs observable to the market, or (2) value the assets based on the most recent trades in the MSR market or (3) mark to the interest-only strip receivable (IO) market as the underlying fundamentals of the MSR and the IO are very similar, meeting the conditions specified for an L2 classification. ${ }^{9}$ Seventy-five percent of Level 2 banks in our sample disclose that they use a DCF model with observable inputs to value the MSRs. Observable inputs include projected prepayment rates and discount rates, which reflect the future cash flow uncertainty related to default and prepayment activities and a liquidity premium. Banks gather these market inputs from a variety of sources,

\footnotetext{
${ }^{9}$ The price of servicing is often express as a multiple of the servicing strip. For example, a 25 basis point strip of MSR's priced at 100 basis points has a multiple of 4 .
} 
including the Security Industry and Financial Markets Association (SIFMA), Mortgage Bankers Association, Bloomburg terminals for macro data, and Fannie Mae and Freddie Mac reports on delinquency rates. Banks that classify their MSRs as Level 3 assets also use a DCF model either developed internally or externally through a third-party valuation specialist. Different from Level 2 fair values, Level 3 fair values are based on managerial inputs that potentially reflect portfolio-specific information about prepayment and foreclosure rates, and changes in discount rates. As these inputs, as well as the underlying mortgages that generate the servicing rights, are not directly observable by the market, Level 3 classification is perceived by market participants to be less verifiable, consistent with the lower tier classification in the fair value hierarchy.

There is very little research examining the accounting and valuation issues surrounding MSRs. Pfeiffer (1998) examines MSRs during the period when originated and purchased MSRs had different accounting treatment, and documents that even though originated MSRs were "off-balance sheet" and expensed as incurred, they were still priced by investors. Pfeiffer (1998) also found evidence that banks were engaging in MSR sales to record discretionary gains that would offset operating losses, providing managers with an opportunity to manage earnings. Aldrich et al (2001) examine the valuation methods and techniques associated with MSRs, relative to the IO market. They document that the spread between the IO market and the MSR market fluctuates substantially over their measurement period (1998-2000). They also document that the valuation of MSRs is significantly influenced by the precision of the prepayment model. However, it important to note that this study was completed before the passage of SFAS 140 and 156. We believe that the recent changes in the accounting treatment for MSRs, the variation in the fair value accounting treatment (Level 2 versus Level 3), including the predominant use of DCF models by Level 2 versus management-influenced models 
for Level 3, provide us with a setting to test the conjecture that certain economic factors (illiquid market, incomplete information) may lead to mark-to-model (Level 3) reports that are of higher quality than marked-to-market (Level 2) valuations. First, MSRs represent a single type of asset with characteristics that justify both Level 2 and Level 3 fair value choices. Second, we can obtain information about the underlying revenue as a noisy proxy for the underlying cash flows generated by the MSR assets ${ }^{10}$. Finally, the availability of both firm-level and macro-level data enables us to examine the relationship between valuations generated by Level 2 and Level 3 models and the associated risk factors.

\subsection{Research Question}

We examine whether Level 3 fair values better reflect the economic characteristics of the underlying servicing portfolios than Level 2 fair values for mortgage servicing rights. If managers manipulate Level 3 fair values inputs to report biased numbers, then we expect to find that Level 3 fair values are less likely to reflect the actual risk factors of the servicing portfolios than Level 2 fair values. However, if Level 3 fair values based on managerial inputs better incorporate managers' private information, we expect to find that Level 3 fair values better reflect the actual risk factors of the servicing portfolios than Level 2 fair values.

\section{Sample and Research Method}

\section{$3.1 \quad$ Sample}

Our sample is drawn from the regulatory report (Y-9C) of bank holding

\footnotetext{
${ }^{10}$ Revenues from servicing follow a "cash flow" process. The remittance agreement between the servicer and the mortgage acquirer determines the flow, as most agreement are based on actual payments from the homeowner to the servicer. Traditional agreements do not require the servicer to make upfront payments of interest and principal to the acquirer.
} 
companies from 2008 to 2011 . We start from 2008 because FAS 157 is effective for all fiscal periods beginning after November 15, 2007. Bank holding companies are required to report the fair value of mortgage servicing assets/liabilities on a quarterly basis in the regulatory reports. Banks classify mortgage servicing as net assets (liabilities) if the expected future revenue is higher (lower) than the adequate compensation. We first identify all banks with non-zero mortgage servicing assets/liabilities. We then read these banks' $10-\mathrm{K}$ and 10-Q reports filed with the SEC to identify whether banks report their mortgage servicing assets/liabilities as Level 2 or Level 3, and collect information disclosed by the banks about amortization costs, fair value adjustments, prepayment rates and discount rates. We also collect information about the amount of servicing revenue generated by the MSRs for each bank-quarter through the SEC filings. We identify 82 unique bank holding companies, all of which report mortgage servicing rights as net assets. These 82 unique bank holding companies generate 978 bank-quarter observations for our full sample analyses. Of the unique 82 bank holding companies, 13 banks always classify their MSRs as L2 assets through the sample period. Four banks classify their MSRs as Level 2 assets first but change the classification during the four-year period to Level 3. Three banks classify the MSRs as Level 3 assets first change the classification Level 2 subsequently. Overall, 20 unique banks classified their MSRs as Level 2 assets for at least one quarter during the sample period. The rest classify their MSRs as L3 assets. Of the unique 20 banks that ever classified the MSRs as Level 2 assets, 15 disclose that they value the MSR assets using a discounted future cash flow model with market inputs. Two banks disclose that they either use discounted future cash flows with market inputs or market quotes, whichever is more appropriate. The remaining three companies do not disclose the specific type of the market inputs. 


\subsection{Research Design}

We first use the following Probit model to investigate why some banks classify their MSRs as L2 assets while others classify their MSRs as L3 assets.

$$
\begin{aligned}
\text { LEVEL }_{i, t} & =\alpha_{0}+\alpha_{1} F O R E \text { RISK } K_{i, t}+\alpha_{2} \text { REFI_RISK } K_{i, t}+\alpha_{3} \text { SUBPRIME }_{i}+\alpha_{4} \text { PROV }_{i, t} \\
& +\alpha_{5} H P I_{i, t}+\alpha_{6} M K T \_L I Q_{, t}+\alpha_{7} M S R / T A_{i, t}+\alpha_{8} S I Z E_{i, t}+\alpha_{9} F V B V_{i t} \\
& +\alpha_{10} A Q_{-} R A N K_{i, t}+\alpha_{11} B I G 4_{i, t}+\varepsilon_{i, t}
\end{aligned}
$$

LEVEL equals 1 when MSRs are classified as Level 3 assets, and 0 when MSRs are classified as Level 2 assets. We include two sets of variables to model the classification choice. The first set includes variables that are related to the characteristics of the underlying servicing portfolios: FORE_RISK, REFI_RISK, SUBPRIME, PROV, and HPI. FORE_RISK is the percentage of the residential mortgage loans serviced for others that are in the process of foreclosure, measured for each bank quarter based on information provided in banks' regulatory reports. In addition to default risk, prepayment risk is another important factor to consider in determining the fair value of the MSRs. Servicing portfolios with a higher level of prepayment rate are considered more risky because the contracted servicing fee for the mortgage servicing assets is a percentage of the outstanding principal balance. We cannot directly observe the expected prepayment rate of the servicing portfolio. However, the prepayment activity during our sample period is predominantly driven by refinancing activity due to the historically low mortgage rates. Therefore, we use the intensity of the refinancing activities in the state where a bank is headquartered to proxy for the prepayment risk. ${ }^{11}$ REFI_RISK is the percentage of refinancing loan amounts scaled by total loan amounts originated for each

\footnotetext{
${ }^{11}$ Based on the disclosed information, most of the MSR assets are derived from banks' own loan originations where loans are subsequently sold with servicing rights retained. If banks tend to originate loans with local borrowers, then refinancing activity within a state where a bank locates would be correlated with the prepayment risk of the underlying servicing portfolios.
} 
state year. ${ }^{12}$ Subprime loans have higher default risk and are less likely to be refinanced.

We obtain the number of subprime loans for each state at the end of 2007 from the Mortgage Bankers Association. We use the quintile raking of number of subprime loans $(S U B P R I M E)$ in a state where a bank is headquartered to proxy for the propensity of subprime mortgages contained in the bank's servicing portfolios. We use $P R O V$, calculated as the provision for loan and lease losses scaled by total interest income measured for each fiscal quarter, to capture the riskiness of the loan portfolios held by the bank on the balance sheet. If banks originate both the on balance sheet loan portfolios and the off balance sheet servicing portfolios, we expect the riskiness of the two portfolios might be correlated. Finally, we include the change in the housing price index (HPI) relative to December 2006 for the state where a bank is headquartered to proxy for the local real estate market conditions.

After controlling for the risk characteristics of the underlying servicing portfolios, we include a second set of variables to explain to what extent the level classification is an accounting choice. We expect that banks are more likely to classify the MSR assets as Level 2 fair value assets when the MSR market is more liquid. We use the total trading volume in the bond market to capture the market wide liquidity, where $M K T L L I Q$ is the monthly total trading volume of the bond market scaled by the total trading volume of the bond market in December 2007. ${ }^{13}$ MSR/TA is the fair value of the MSR at the end of the fiscal quarter scaled by total assets, capturing the importance of the MSR valuation from the economic magnitude perspective. $F V B V$ is an indicator variable that equals 1 if a

\footnotetext{
${ }^{12}$ Information related to state level refinancing activity is acquired from Federal Financial Institutions Examination Council (FFIEC) website.

${ }^{13}$ There is no readily available measure for the liquidity of the MSR market. Since the revenue generated from the MSR assets is similar to an Interest Only strip receivable, we contend that the bond market liquidity is likely to be more relevant than the equity market liquidity.
} 
bank adopts fair value reporting for its MSRs and 0 if a bank adopts lower of cost or market reporting for its MSRs. We use $F V B V$ to capture the importance of the valuation of MSRs from a financial reporting perspective. As MSRs become more important, we expect that banks are more likely to report MSRs as Level 3 assets if concerns about market inputs outweigh the benefits of Level 2 reporting. We measure SIZE as the natural $\log$ of total assets. Since banks often hire an independent consulting company to value the MSRs, we expect larger banks are more likely to be able to bear the model valuation costs as explained in Emrick (2006) and therefore SIZE should be positively associated with $L E V E L$. One concern often expressed about fair value accounting that is marked to model is that it provides managers with opportunities to manipulate asset values and the related gains and losses, and potentially manage their earnings reports. We include $A Q \_R A N K$, measured as the quintile rank of the estimated coefficient $\left(\beta_{l}\right)$ of the following regression $C H A R G E_{t+1}=\beta_{0}+\beta_{1}$ PROVISION $_{t}+\varepsilon_{t}$. This regression is estimated for firm $i$ quarter $t$ using the information of from quarter $t-8$ to $t$. As is in Altamuro and Beatty (2010), the relationship between the loan loss provision and next period charge-offs serves as a measure of loan-loss provision validity. If managers are choosing L3 classification to manage earnings, we would expect that choice to be associated with a less valid loan-loss provision. Finally, we include an indicator variable which equals 1 for banks with big four auditors and 0 otherwise. We do not have a signed prediction for this variable because, while big auditors may prefer a verifiable measure (level 2), they also have the resources and expertise to audit a more complex discounted cash flow model with managerial inputs.

After investigating the determinants of the level classification, we use equation (2) to examine the persistence of the mortgage servicing fees to learn more about the 
characteristics of the MSR assets, where Servicing Fee $i, t$ is the servicing revenue earned by bank $i$ for quarter $t .^{14}$

$$
\text { Servicing Fee } e_{i, t+1}=\beta_{0}+\beta_{1} \text { Servicing Fee } e_{i, t}+\beta_{2} S_{I Z E_{i, t}}+\varepsilon_{i, t}
$$

We use the estimated servicing fee persistence as a summary measure of the riskiness of the underlying servicing portfolios. A more persistent stream of serving revenue suggests that the MSR assets are less affected by foreclosures and prepayments, which represent less risk for the MSR assets. Since the variables measuring the risk characteristics of the underlying servicing portfolios are not perfect in equation (1), we use the estimated servicing fee persistence to corroborate the estimation results in the Probit model. If the results from the Probit model suggest that the servicing portfolios for Level 2 MSR is less (more) risky, we would expect the service fee generated by Level 2 MSRs to be more (less) persistent.

We use the following two equations to examine whether the fair value measurements reflects the risk characteristics of the underlying MSR assets.

$$
\begin{aligned}
& M S R_{i, t}=\gamma_{0}+\gamma_{1} \text { Servicing Fee }_{i, t}+\gamma_{2} \text { SIZE }_{i, t}+\gamma_{3} \text { Beta_Rank }_{i}+ \\
& \gamma_{4} \text { Beta_Rank }_{i} * \text { Servicing Fee } \text { Ret }_{i}+\varepsilon_{i, t} \\
& M_{i, t}=\delta_{0}+\delta_{1} \text { Servicing Fee } e_{i, t}+\delta_{2} \text { SIZE }_{i, t}+\delta_{3} \text { REFI_RISK } K_{i, t}+\delta_{4} F_{\text {FORE_RISK }} \\
& +\delta_{5} \text { REFI_RISK } K_{i t} * \text { Servicing Fee } e_{i, t}+\delta_{6} \text { FORE_RISK }_{i t} * \text { Servicing Fee } e_{i, t}+\varepsilon_{i, t}
\end{aligned}
$$

Where Beta_Rank is the quartile rank variable of the persistence of the net servicing fee estimated for each bank following equation (2). ${ }^{15}$ We use the rank variable to minimize the estimation noise. For a fair value measurement that represents the economic substance of the underlying mortgage assets, we expect to observe higher valuation multiples for less risky servicing portfolios. Specifically, we expect to find higher

\footnotetext{
${ }^{14}$ Buttimer and Lin (2005) explain that MSR servicers incur significant upfront costs building computing and customer-service infrastructure. The costs of servicing and the "adequate compensation" are mainly fixed. Therefore, expected future servicing revenue is the most important valuation factor.

${ }^{15}$ We require at least 8 quarterly observations to estimate bank-specific servicing fee persistence.
} 
valuation multiples for more persistent revenue streams $\left(\gamma_{4}>0\right)$. We also expect to find lower valuation multiples for servicing portfolios with higher prepayment risk $\left(\delta_{5}<0\right)$ and higher default risk $\left(\delta_{6}<0\right)$. We estimate equations (3) and (4) for the Level 2 and Level 3 subsamples separately, and then test whether the estimated $\gamma_{4}, \delta_{5}$, and $\delta_{6}$ coefficients are different across the two samples. ${ }^{16}$

\section{Empirical Results}

\subsection{Descriptive Analysis}

Table 1 provides descriptive statistics about our sample. We find that firms that classify their MSRs as Level 3 assets tend to hold riskier portfolios both on the balance sheet and off the balance sheet. For example, the average loan loss provision (PROV) for Level 3 banks is $24.89 \%$ compared with $15.02 \%$ for Level 2 banks, suggesting Level 3 banks hold riskier loans on their balance sheet. We find $0.85 \%$ of residential loans serviced by Level 3 banks are in foreclosure, which is significantly higher than $0.14 \%$ serviced by Level 2 banks. In addition, Level 3 banks are located in states with a steeper drop in housing prices (lower HPI), a higher number of subprime mortgages right before the crisis period, and slightly lower refinancing activity. Since the majority of the servicing portfolios come from loans originated by the bank, especially for smaller banks, the above findings suggest that Level 3 servicing portfolios have a higher default risk on average if small banks are more likely to originate local loans. For variables that capture incentives for accounting choices, we find Level 3 banks have a larger amount of MSRs as a percentage of total assets and are more likely to adopt the fair value option for their MSRs, suggesting that the MSR valuation is more important for these banks. We find Level 3 banks are much larger (as measured by asset size) and are more likely to have

\footnotetext{
${ }^{16}$ For presentation and interpretation clarity, we run the regressions for the two subsamples separately. We obtain the same results if we estimate the regressions for the pooled sample with three-way interaction terms.
} 
one of the big four auditors, suggesting Level 3 banks have more resources to measure the fair value for sophisticated financial instruments. Finally, we find the accounting quality (measured by the ability of the loan loss provision to predict future write-offs) for Level 3 banks is higher than that for Level 2 banks.

We provide Spearman rank correlations of our variables of interest in Table 2. Similar to the descriptive statistics presented in Table 1, we find the level choice is positively correlated with number of subprime loans $(\rho=0.23)$, size $(\rho=0.31)$ and choice of the big four auditors $(\rho=0.35)$ and negatively correlated with changes in housing price index $(\rho=-0.18)$. We also find that larger banks report higher loan loss provisions, have more serving assets, are more likely to use fair value option for their servicing assets, and serve more loans that are in the process of foreclosure. We find the correlations between changes in the housing price index and number of subprime loans $(\rho=-0.30)$ and loan loss provisions $(\rho=-0.21)$ to be significantly negative, suggesting loans originated in states with steeper housing price drops have higher credit risk. We find the correlation between HPI and REFI_RISK to be significantly negative, suggesting states with steeper housing price drops also have more refinancing activity. Finally, we find that the indicator variable for fair value adoption is significantly positively correlated with the probability of the Level 3 classification and choice of big four auditors.

\subsection{Determinants of Level 2 versus Level 3 classification}

In Table 3, we report the regression results for the Probit model examining the determinants of fair value classification choice. Our findings suggest that the levels classification is affected by both the characteristics of the underlying servicing portfolios and managerial choices. Consistent with the descriptive statistics reported in Table 1, the servicing portfolios for mortgage servicing rights classified as Level 3 assets have higher 
default risk. The estimated coefficient for FORE_RISK is significantly positive at the $1 \%$ level. The estimated coefficient is significantly negative for HPI and positive for SUBPRIME, suggesting Level 3 banks are more likely to be located in the states with steeper drops in housing price and a higher number of subprime loans. The estimated coefficient for REFI_RISK is negative but not significantly different from zero. In sum, if banks are more likely to originate loans in their local market, the above findings suggest that the servicing portfolios for Level 3 banks have higher credit risk than that for Level 2 banks, but not higher prepayment risk caused by refinancing. In addition to the characteristics of the underlying service portfolio, we find smaller banks are more likely to use market inputs to value the MSR assets, consistent with the argument that hiring an external independent valuation agency or developing internal models is too costly for smaller banks. We also find that banks that have more MSR assets and choose the fair value option for MSRs are more likely to choose Level 3 classification, consistent with the argument that banks choose to use firm-specific inputs when MSRs are more important either from an economic magnitude perspective or for financial reporting purposes. We do not find evidence consistent with an association between lower accounting quality and the Level 2 versus Level 3 classification choice. Finally, after controlling for size, we still find firms with big four auditors are more likely to use firmspecific model inputs and classify the MSR fair value as level 3.

\subsection{Persistence of servicing fees for Level 2 and Level 3 MSRs}

We use the persistence of servicing fees associated with the MSR assets as a summary measure of the underlying riskiness of the servicing portfolio and report the regression results in Table 4. Column (1) reports regression results for equation (2) for the full sample. Since regression results from Table 3 suggest that both bank 
characteristics and the risk characteristics of the underlying servicing portfolios affect the fair value level classification, we also match Level 2 banks with Level 3 banks on dimensions such as fair value option choice, geographic location, and size and report regression results in column (2), (3), and (4). For the full sample, we find that servicing fees generated by Level 2 MSRs are highly persistent. For example, the estimated coefficient of $\beta_{l}$ is 0.6482 for Level 2 MSRs, significantly higher than zero ( $p$-value $=$ 0.0001). We find the estimated coefficient for the interaction term LEVEL* Servicing fee to be -0.2776 but not statistically significant $(p$-value $=0.1235)$, suggesting the cash flow persistency for Level 3 MSRs is not statistically different from that for the Level 2 MSRs.

To control for the accounting choice between fair value option and the lower of cost or market option, we restrict the regression analysis to the sub-sample that only adopt lower of cost or market valuation option and report the results in Table 4 column (2). The estimated coefficient for the interaction term LEVEL * Servicing fee is significantly negative with a $p$-value of 0.0789 , suggesting significantly lower persistence for servicing fee revenue for MSRs reported as Level 3 assets. To further control for the risk characteristics of the underlying service portfolios caused by geographic locations, we further restrict the regression analysis to include only Level 3 banks located in the same states as the Level 2 banks and still find that cash flows for Level 3 MSRs are less persistent than cash flows for Level 2 MSRs. The above results are consistent with the Probit model regression results reported in Table 3 and suggest that Level 2 MSRs are, on average, less risky than Level 3 MSRs. Finally, we match each Level 2 bank with a Level 3 bank on the lower of costs or market valuation option, changes in state level housing price index, and size. Results reported in column (4) suggest that after matching on the 
above three dimensions, the difference of cash flow persistency between Level 2 MSRs and Level 3 MSRs is not significantly different. Therefore, we believe the risk characteristics of the underlying servicing portfolios for Level 2 MSRs and Level 3 MSRs are similar after matching on the above three dimensions.

\subsection{Comparison between Level 2 and Level 3 MSR fair values}

We report our first set of main tests in Table 5, where we examine which fair value for MSRs better reflect the persistence of the underlying cash flow process. If the MSR asset value represents the economic substance of the underlying cash flow process, we expect the valuation multiple to be positively associated with the persistence of the cash flows $\left(\gamma_{4}>0\right)$. That is, we expect a higher valuation multiple for less risky cash flows. Table 5 Column (1) show that we do not find this relationship for fair values of MSRs classified as Level 2 assets. The estimated coefficient of $\gamma_{4}$ in column (1) is negative $0.0976(p$-value $=0.8557)$. For fair value of MSRs based on managerial inputs (Level 3), we find $\gamma_{4}$ to be significantly positive for all four samples. For example, the $\gamma_{4}$ estimate for Level 3 fair value for all banks is 1.4980 as reported in Column (2), significantly higher than zero $(p$-value $=0.0532)$. For banks that classify their MSRs as

Level 3 assets and also adopt lower of cost or market valuation option for MSRs reported in Column (3), the estimated coefficient of $\gamma_{4}$ is $1.4648 \quad(p$-value $=0.0636)$. For banks that classified their MSRs as Level 3 assets, adopt lower of cost or market valuation options, and locate in the same state as banks reporting Level 2 MSRs, the estimated coefficient of $\gamma_{4}$ is 1.5958 (p-value $\left.=0.0009\right)$. Finally, for banks that classified their MSRs as Level 3 assets, adopt lower of cost or market valuation options, have similar size as Level 2 banks, and experience similar housing market conditions during the sample period, the estimated coefficient of $\gamma_{4}$ is $1.5212(p$-value $=0.0199)$. In sum, our 
results suggest that the valuation multiple of fair value measurements based on managerial inputs (Level 3) is significantly positively associated with the cash flow persistence, whereas we do not find this positive association for fair values based on market inputs (Level 2). ${ }^{17}$ We also show that the difference between the two samples are not driven by the difference in the underlying service portfolios because Table (4) Column (4) shows that the persistence of servicing fee is the same across the two samples after matching on lower of costs or market valuation choice, HPI, and size. We contend that this finding provides direct evidence of the conjectures made in Ryan (2008), that certain unobservable managerial inputs may be of higher quality and more useful that observable market inputs.

As a supplemental analysis, we consider the impact of disclosures on the financial characteristics of MSR reporting. In Table 5, Panel B, we find that only banks that disclose prepayment and discount rate assumptions in their annual report generate MSR fair value measurements that are statistically positively associated with the persistence of cash flows. The result is consistent with the argument that banks that choose more transparent financial reporting through additional disclosures tend to generate more reliable fair value measures based on managerial inputs.

We report our second set of main tests in Table 6, where we examine which fair value for MSRs better reflect the prepayment risk and default risk of the underlying service portfolios. We use the state-level refinancing activity to capture the prepayment risk (REFI_RISK). We use percentage of loans serviced in foreclosure to capture default risk (FORE_RISK). If the MSR fair value measurement reflects the risk characteristics,

\footnotetext{
${ }^{17}$ We obtain the same results if we combine the two subsamples and run pooled regressions with three-way interactions. Moreover, we find that the three-way interaction term is significantly positive, suggesting Level 3 fair value is statistically more sensitive to the risk characteristics of the underlying service portfolios than Level 2 fair value.
} 
we expect to find both $\delta_{5}$ and $\delta_{6}$ to be significantly negative in equation (4). Table 6 , Column (1) documents that for Level 2 banks, the estimated coefficient is -2.0351 ( $p$ value $=0.6384)$ for REFI_RISK and $-30.69(p$-value $=0.5028)$ for FORE_RISK. Neither is significantly different from zero. In contrast, the coefficient estimates for REFI_RISK and FORE_RISK are significantly negative for Level 3 fair values across all specifications. For example, Column (5) reports that the estimated coefficient for REFI_RISK is negative $10.04(p$-value $=0.0325)$, suggesting that increase in one standard deviation of the prepayment risk proxied by state-level refinancing activity reduces the valuation multiple by 0.72 . Column (5) also reports that the estimated coefficient for FORE_RISK is negative $104.51(p$-value $=0.0158)$, suggesting that an increase in one standard deviation of the default risk proxied by percentage of loans serviced in foreclosure reduces the valuation multiple by 0.84 . Overall, the results reported in Table 6 Panel A are consistent with the results reported in Table 5 Panel A and suggest that fair value based on managerial inputs better reflects the risk characteristics of the underlying servicing portfolios.

Table 6 Panel B reports the regression results of equation (4) partitioning the Level 3 banks based on whether they disclose prepayment rates and discount rates in the annual reports filed to the SEC. We find results consistent with the argument that banks that disclosure the firm-specific modeling inputs generate better fair value measurements.

\subsection{Robustness Tests}

Our sample period consists of both a recession period 2008-2009 and a postrecession period 2010-2011. Since both the MSR market liquidity and the incentives to provide informative managerial estimates might be different across the two periods, we also examine our research question and conduct the main tests for the two periods 
separately. We find that, on average, both the servicing fee persistency and the MSR valuation multiple increases from the recession period to the post-recession period, consistent with the observation that the servicing portfolio experiences lower default risk and refinancing risk in the post-recession period. However, our results that Level 3 fair value better reflects the risk characteristics hold for both periods.

In our main tests, we only match Level 3 banks with Level 2 banks on the most important dimensions indicated by our determinants model, such as size, geographic location, and adoption of the fair value accounting option. As a robustness check, we also match Level 3 banks with Level 2 banks on alternative firm characteristics such as whether a bank engages a big four auditor. Our results do not change based on this specification. However, the small sample size limits our matching process to at most three factors and it is impractical to conduct propensity score matching based on all available information.

Finally, we explore the sensitivity of our REFI_RISK variable. Rather than measure only in the state where the corporate headquarters are located, we also measure REFI_RISK as a weighted-average of the state-level refinancing rates where the bank has operating activity, proxied by the percentage of branch deposits in that particular state. We find 30 banks in our sample operate only in home states. Thirty-one banks operate between two and five states with $79 \%$ of business conducted in the home states where they have their headquarters. Therefore, it is reasonable to argue that refinancing activity in the headquarters' states would capture the relevant refinancing activity. In addition, the correlation between our original REFI_RISK variable measure and this modified REFI_RISK measure is 0.93 . We obtain very similar results based on the modified refinancing risk measure. 


\section{Conclusions}

In this paper, we collect a sample of banks that have mortgage servicing rights subject to Level 2 and Level 3 classification in accordance with the SFAS 157 fair value hierarchy. We examine the financial reporting characteristics of these fair value assets, and whether those characteristics differ across the classification levels. We first examine the determinants of the levels classification, and find evidence that bank size, accounting choice and mortgage risk attributes are associated with the levels classification decision. Through an examination of the persistence of servicing fees and the association between the MSR valuation multiple and underlying mortgage risk factors, we provide evidence that during periods of infrequent trading and market illiquidity, valuations from models that reflect management's input and expertise provide an MSR asset value that is more closely associated with the underlying cash flows. This finding is consistent with conjectures made by Ryan (2008) that a welldeveloped model may provide more useful information to investors than reliance on weaker market inputs.

Additionally, we contend that our study makes a contribution to the literature by thinking about valuation and accounting choices in a way that is similar to the approach taken by managers, at the transaction level. By focusing on one particular type of asset with a discernible cash flow process, we are able to incorporate variables that are directly related to the risks and rewards associated with mortgage servicing rights. Consequently, we are not making inferences based on an aggregation of heterogeneous risks and processes. By narrowing our focus, we believe that a greater understanding of the managerial decision-making process with respect to fair value accounting can be realized, and that the results of this study will be particularly relevant to the ongoing 
debate about the role of fair values in financial reporting, and what financial reporting characteristics are necessary to generate decision-useful financial information. 


\section{References}

Aboody, David, Mary Barth, and Ron Kasznik, 1999. Revaluations of Fixed Assets and Future Firm Performance: Evidence from the UK. Journal of Accounting and Economics 26, 149-178.

Aldrich, Simon, William R. Greenberg, and Brook Payner, 2001. A Capital Markets View of Mortgage Servicing Rights. The Journal of Fixed Income Vol 11, 37-53.

Altamuro, Jennifer, Anne L. Beatty, 2010 "How Does Internal Control Regulation Affect Financial Reporting?" Journal of Accounting and Economics, Vol. 49, Issue 1-2, 5874 .

American Banking News (ABN). Mortgage Servicing Rights Write-downs Could Crush Banks Earnings for Quarter, October 2009.

Brown, S., Hayre, L. S., Lauterbach, K., Payne, R., \& Zimmerman, T. 1992. Analysis of mortgage servicing portfolios. The Journal of Fixed Income, 2(3), 60-75.

Botosan, Christine, Richard Carrizosa, and Adrienna Huffman, 2011. Factors Influencing Banks' Use of Level 3 Valuation Inputs During the Financial Crisis, working paper, University of Utah.

Buttimer, Richard and Che-Chun Lin, 2005. Valuing US and Canadian Mortgage Servicing Rights with Default and Prepayment. Journal of Housing Economics 14, 194-211.

Cotter, J., \& Richardson, S. 2002. Reliability of asset revaluations: The impact of appraiser independence. Review of Accounting Studies, 7(4), 435-457.

Dietrich, Richard, Mary Harris, and Karl Muller, 2001. The Reliability of Investment Property Fair Value Estimates. Journal of Accounting and Economics 30, 125-158.

Emrick, Craig, New FASB Statement Requires Initial Fair Value Treatment for Servicing Assets and Liabilities - Look for Increases in Gain on Sale Revenues at Mortgage Companies (May 2006). Moody's Investor Services.

FASB (2008), FASB Staff Position. FSP FAS 157-3, October 10, 2008.

FASB (2009), FASB Staff Position, FSP FAS 157-4, April 9, 2009.

Goh, Beng Wee, Jeffrey Ng, and Kevin Ow Yong, 2009. Market Pricing of Banks' Fair Value Assets Reported under SFAS 157 During the 2008 Economic Crisis, working paper, MIT.

Kolev, K. 2009. Do investors perceive marking-to-model as marking-to-myth? Early evidence from FAS 157 disclosure. Working Paper. New York University. 
Laux, Christian and Christian Leuz, 2009. The crisis of fair-value accounting: Making sense of the recent debate. Accounting, Organizations and Society, Vol 34 pp 826834.

Laux, Christian and Christian Leuz, 2010. Did Fair Value Accounting Contribute to the Financial Crisis? The Journal of Economic Perspectives, Vol 24, No. 1 pp 93-118.

Maines, Laureen and James Wahlen, 2006. The Nature of Accounting Information Reliability: Inference from Archival and Experimental Research. Accounting Horizons 20, 399-425

Muller, Karl, 1999. An Examination of the Voluntary Recognition of Acquired Brand Names in the United Kingdom. Journal of Accounting and Economics 26, 179-191.

Rettinger, Thomas and Charles Richard. Market for Mortgage Servicing Rights. December 2002.

Riedl, Edward, and George Serafeim, 2009. Information Risk and Fair Value: An Examination of Equity Betas and Bid-Ask Spreads. Working Paper, Harvard Business School.

Ryan, Stephen G. (2008) Accounting in and for the Subprime Crisis. The Accounting Review: November 2008, Vol. 83, No. 6, pp. 1605-1638.

Sloan, Richard, 1999. Evaluating the Reliability of Current Value Estimates. Journal of Accounting and Economics 26, 193-200.

Song, Chang Joon, Wayne Thomas, and Han Yi. Value Relevance of FAS No. 157 Fair Value Hierarchy Information and the Impact of Corporate Governance Mechanisms. The Accounting Review 85, 1375-1410.

Urumoglu, Urum, 2010. Demystifying the Valuation of Mortgage Servicing Rights. www.cunacfocouncil.org

Wang, Karl, 2010. Negotiating a Fair Value under Accounting Uncertainty: A Laboratory Experiment. Behavior Research in Accounting 22, 109-134. 
Table 1: Descriptive statistics

\begin{tabular}{|l|c|c|c|c|c|c|}
\hline & $\begin{array}{c}\text { Level 2 } \\
\text { (Mean) }\end{array}$ & $\begin{array}{c}\text { Level 2 } \\
\text { (Median) }\end{array}$ & $\begin{array}{c}\text { Level 3 } \\
\text { (Mean) }\end{array}$ & $\begin{array}{c}\text { Level 3 } \\
\text { (Median) }\end{array}$ & $\begin{array}{c}\text { Difference } \\
\text { in Means }\end{array}$ & $\begin{array}{c}\text { Difference } \\
\text { in Medians }\end{array}$ \\
\hline FORE_RISK & 0.0014 & 0 & 0.0085 & 0.0018 & $* * *$ & $* * *$ \\
\hline HPI & -0.0745 & -0.0549 & -0.1134 & -0.0895 & $* * *$ & $* * *$ \\
\hline REFI_RISK & 0.5989 & 0.5969 & 0.5845 & 0.5815 & $*$ & $*$ \\
\hline SUBPRIME & 1.4098 & 1 & 2.1808 & 2 & $* * *$ & $* * *$ \\
\hline PROV & 0.1502 & 0.1255 & 0.2489 & 0.1669 & $* * *$ & $* *$ \\
\hline MKT_LIQ & 1.6235 & 1.6694 & 1.6507 & 1.7502 & & \\
\hline SIZE & 7.7015 & 7.7503 & 9.2110 & 9.0087 & $* * *$ & $* * *$ \\
\hline MSR/TA & 0.0017 & 0.0014 & 0.0024 & 0.0015 & $* * *$ & \\
\hline FVBV & 0.0245 & 0 & 0.4362 & 0 & $* * *$ & $* * *$ \\
\hline AQ & 1.7395 & 1 & 2.1265 & 2 & $* * *$ & $* * *$ \\
\hline BIG4 & 0.2418 & 0 & 0.6619 & 1 & $* * *$ & $* * *$ \\
\hline N & 192 & 192 & 786 & 786 & & \\
\hline
\end{tabular}

${ }^{* * *}, * *, *$ indicate significance level at $1 \%, 5 \%$, and $10 \%$, respectively.

Variable definitions:

FORE_RISK is the percentage of the residential mortgage serviced for others that are in process of foreclosure, measured for each bank quarter. $\boldsymbol{H P I}$ is the change in housing price index relative to December 2006 measured for each state quarter. $\boldsymbol{R} \boldsymbol{E} \boldsymbol{F I} \boldsymbol{R} \boldsymbol{I S K}$ is the percentage of refinancing loan amounts scaled by total loan amounts, measured for each state year. SUBPRIME is the quintile rank of the number of subprime mortgages at the end of 2007, measured for each state. PR $\boldsymbol{O} \boldsymbol{V}$ is the provision for loan and lease losses scaled by total interest income measured for each bank quarter. $\boldsymbol{M K} \boldsymbol{T} \_\boldsymbol{L I} \boldsymbol{Q}$ is the total trading volume of the bond market scaled by the total trading volume of the bond market in December 2007 , measured for each month. SIZE is the natural log of beginning total assets, measured for each bank quarter. $\boldsymbol{M S R / T \boldsymbol { A }}$ is the fair value of the mortgage servicing right at the end of the fiscal quarter scaled by total assets. $\boldsymbol{F} \boldsymbol{V} \boldsymbol{B} \boldsymbol{V}$ is an indicator variable that equals one if a company chooses the fair value reporting option for its MSRs. $\boldsymbol{A} \boldsymbol{Q}$ is the quintile rank of the estimated coefficient $\left(\beta_{l}\right)$ of the following regression $C H A R G E_{t+1}=\beta_{0}+\beta_{l} P R O$ VISION $_{t}+\varepsilon_{t}$. This regression is estimated for firm $i$ quarter $t$ using the information from quarter $t-8$ to $t$. BIG4 is an indicator variable equal to 1 for banks that use big 4 auditors and 0 otherwise. 
Table 2: Correlations of main variables.

\begin{tabular}{|l|c|c|c|c|c|c|c|c|c|c|c|}
\hline & $(2)$ & $(3)$ & $(4)$ & $(5)$ & $(6)$ & $(7)$ & $(8)$ & $(9)$ & $(10)$ & $(11)$ & $(12)$ \\
\hline LEVEL (1) & $\mathbf{0 . 2 1}$ & 0.05 & $\mathbf{- 0 . 1 8}$ & $\mathbf{0 . 2 3}$ & 0.07 & 0.04 & 0.03 & $\mathbf{0 . 3 1}$ & $\mathbf{0 . 3 5}$ & $\mathbf{0 . 1 2}$ & $\mathbf{0 . 3 5}$ \\
\hline FORE_RISK (2) & 1.00 & $\mathbf{- 0 . 0 8}$ & $\mathbf{- 0 . 2 0}$ & $\mathbf{0 . 1 0}$ & $\mathbf{0 . 2 1}$ & $\mathbf{0 . 0 9}$ & $\mathbf{0 . 2 6}$ & $\mathbf{0 . 4 7}$ & $\mathbf{0 . 1 9}$ & $\mathbf{0 . 1 2}$ & $\mathbf{0 . 2 9}$ \\
\hline REFI_RISK (3) & & 1.00 & $\mathbf{- 0 . 2 1}$ & $\mathbf{- 0 . 0 8}$ & $\mathbf{0 . 1 8}$ & $\mathbf{0 . 1 5}$ & $\mathbf{- 0 . 1 9}$ & $\mathbf{- 0 . 2 1}$ & $\mathbf{- 0 . 1 5}$ & 0.02 & $\mathbf{- 0 . 2 2}$ \\
\hline HPI (4) & & & 1.00 & $\mathbf{- 0 . 3 0}$ & $\mathbf{- 0 . 2 1}$ & $\mathbf{- 0 . 2 4}$ & 0.00 & -0.06 & $\mathbf{- 0 . 1 3}$ & -0.06 & 0.07 \\
\hline SUBPRIME(5) & & & & 1.00 & $\mathbf{0 . 1 3}$ & -0.01 & -0.02 & $\mathbf{0 . 1 2}$ & 0.06 & $\mathbf{0 . 1 6}$ & $\mathbf{0 . 1 0}$ \\
\hline PROV (6) & & & & & 1.00 & $\mathbf{0 . 1 8}$ & $\mathbf{0 . 1 9}$ & $\mathbf{0 . 3 2}$ & $\mathbf{0 . 2 6}$ & $\mathbf{0 . 2 0}$ & 0.10 \\
\hline MKT_LIQ(7) & & & & & & 1.00 & $\mathbf{0 . 0 9}$ & 0.03 & 0.03 & -0.03 & 0.00 \\
\hline MSR/TA(8) & & & & & & & 1.00 & $\mathbf{0 . 3 2}$ & $\mathbf{0 . 3 9}$ & 0.03 & $\mathbf{0 . 1 7}$ \\
\hline SIZE (9) & & & & & & & & 1.00 & $\mathbf{0 . 5 0}$ & $\mathbf{0 . 1 9}$ & $\mathbf{0 . 6 5}$ \\
\hline FVBV(10) & & & & & & & & & 1.00 & $\mathbf{0 . 0 9}$ & $\mathbf{0 . 3 1}$ \\
\hline AQ(11) & & & & & & & & & & 1.00 & $\mathbf{0 . 1 4}$ \\
\hline BIG4(12) & & & & & & & & & & & 1.00 \\
\hline
\end{tabular}

Numbers in bold indicates $1 \%$ level of significance.

Variable definitions:

$\boldsymbol{L} \boldsymbol{E} \boldsymbol{V E} \boldsymbol{L}$ is an indicator variable that equals 1 for bank-quarters reporting MSRs as level 3 assets and 0 for bank-quarters reporting MSRs as level 2 assets. FORE_RISK is the percentage of the residential mortgage serviced for others that are in process of foreclosure, measured for each bank quarter. $\boldsymbol{R} \boldsymbol{E} \boldsymbol{F I} \boldsymbol{R} \boldsymbol{I S K}$ is the percentage of refinancing loan amounts scaled by total loan amounts, measured for each state year. $\boldsymbol{H P I}$ is the changes in housing price index relative to December 2006 measured for each state quarter.

SUBPRIME is the natural log of number of subprime mortgages at the end of 2007, measured for each state. PROV is the provision for loan and lease losses scaled by total interest income measured for each bank quarter. $\boldsymbol{M K} \boldsymbol{T}_{-} \boldsymbol{L I} \boldsymbol{Q}$ is the total trading volume of the bond market scaled by the total trading volume

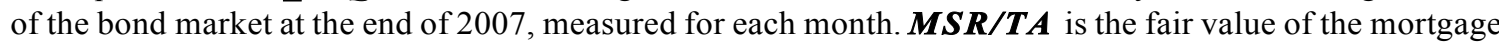
servicing right at the end of the fiscal quarter scaled by total assets, measured for each bank quarter. SIZE is the natural log of beginning total assets, measured for each bank quarter. $\boldsymbol{F} \boldsymbol{V} \boldsymbol{B} \boldsymbol{V}$ is an indicator variable that equals one if a company chooses the fair value reporting option for its MSRs. $\boldsymbol{A} \boldsymbol{Q}$ is the quintile rank of the estimated coefficient $\left(\beta_{l}\right)$ of the following regression $C H A R G E_{t+1}=\beta_{o}+\beta_{I} P R O V I S I O N_{t}+\varepsilon_{t}$. This regression is estimated for firm $i$ quarter $t$ using the information from quarter $t-8$ to $t$. $\boldsymbol{B I G} \mathbf{G}$ is an indicator variable equal to 1 for banks that use big 4 auditors and 0 otherwise. 
Table 3: PROBIT Model regression results for Level 2 versus Level 3 classification.

$$
\begin{aligned}
& \text { LEVEL }_{i, t}=\alpha_{0}+\alpha_{1} \text { FORE_RISK } K_{i, t}+\alpha_{2} \text { REFI_RISK } K_{i, t}+\alpha_{3} S U B P R I M E_{i}+\alpha_{4} P R O V_{i, t} \\
& +\alpha_{5} H P I_{i, t}+\alpha_{6} M K T \_L I Q_{, t}+\alpha_{7} M S R / T A_{i, t}+\alpha_{8} S I Z E_{i, t}+\alpha_{9} F V B V_{i t} \\
& +\alpha_{10} A Q_{-} R A N K_{i, t}+\alpha_{11} B I G 4_{i, t}+\varepsilon_{i, t}
\end{aligned}
$$

\begin{tabular}{|l|l|l|}
\hline & $\begin{array}{l}\text { Estimated } \\
\text { Coefficients }\end{array}$ & P-value \\
\hline \multicolumn{3}{|l|}{ Proxy for the riskiness of the underlying servicing portfolios } \\
\hline FORE_RISK & 0.0771 & $(0.0018)^{* * *}$ \\
\hline REFI_RISK & -0.2532 & $(0.1264)$ \\
\hline HPI & -0.3027 & $(0.0154)^{* *}$ \\
\hline SUBPRIME & 0.0488 & $(0.0001)^{* * *}$ \\
\hline PROV & -0.0192 & $(0.6517)$ \\
\hline \multicolumn{3}{|l|}{} \\
Determinants of the accounting choice \\
\hline MKT_LIQ & 0.0708 & $(0.2606)$ \\
\hline MSR/TA & 18.387 & $(0.0011)^{* * *}$ \\
\hline SIZE & 0.1723 & $(0.0425)^{* *}$ \\
\hline FVBV & 0.2473 & $(0.0001)^{* * *}$ \\
\hline AQ & 0.0049 & $(0.5449)$ \\
\hline BIG4 & 0.1999 & $(0.0001)^{* * *}$ \\
\hline Intercept & 0.5994 & $(0.0001)^{* * *}$ \\
\hline N & 978 & \\
\hline Pseudo R ${ }^{2}$ & $32.61 \%$ & \\
\hline
\end{tabular}

$* * *, * *,{ }^{*}$ indicates significance level at $1 \%, 5 \%$, and $10 \%$, respectively.

Two-tailed p-values are reported in parentheses. Standard errors are clustered at firm level.

Variable definitions:

$\boldsymbol{L E} \boldsymbol{V E \boldsymbol { E }}$ is an indicator variable that equals 1 for bank-quarters reporting MSRs as level 3 assets and 0 for bank-quarters reporting MSRs as level 2 assets. FORE_RISK is the percentage of residential mortgage serviced for others that are in process of foreclosure, measured for each bank quarter. $\boldsymbol{R} \boldsymbol{E} \boldsymbol{F I} \boldsymbol{R} \boldsymbol{I S \boldsymbol { K }}$ is the percentage of refinancing loan amounts scaled by total loan amounts, measured for each state year.

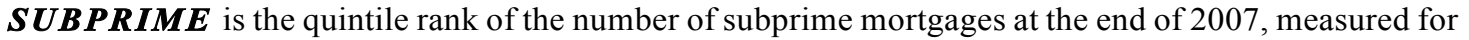
each state. $\boldsymbol{P R} \boldsymbol{O} \boldsymbol{V}$ is the provision for loan and lease losses scaled by total interest income measured for each bank quarter. $\boldsymbol{H P I}$ is the changes in housing price index relative to December 2006 measured for each state quarter. MKT_LIQ is the total trading volume of the bond market scaled by the total trading volume of the bond market at the end of 2007, measured for each month. $\boldsymbol{M S R / T \boldsymbol { A }}$ is the fair value of the mortgage servicing right at the end of the fiscal quarter scaled by total assets, measured for each bank quarter. SIZE is the natural $\log$ of beginning total assets, measured for each bank quarter. $\boldsymbol{F} \boldsymbol{V} \boldsymbol{B} \boldsymbol{V}$ is an indicator variable that equals one if a company chooses the fair value reporting option for its MSRs. $\boldsymbol{A} \boldsymbol{Q}$ is the quintile rank of the estimated coefficient $\left(\beta_{l}\right)$ of the following regression $C H A R G E_{t+1}=\beta_{0}+\beta_{I} P R O V I S I O N_{t}+\varepsilon_{t}$. This regression is estimated for firm $i$ quarter $t$ using the information from quarter $t-8$ to $t$. BIG4 is an indicator variable equal to 1 for banks that use big 4 auditors and 0 otherwise. 
Table 4: Persistence of servicing fees

Servicing Fee $e_{i, t+1}=\beta_{0}+\beta_{1}$ Servicing Fee ${ }_{i, t}+\beta_{2}$ SIZE $_{i, t}+\beta_{3} L E V E L_{i, t}$

$+\beta_{4} L E V E L_{i, t} *$ Servicing Fee $i, t+\varepsilon_{i, t}$

\begin{tabular}{|l|c|c|c|c|}
\hline & Full Sample & $\begin{array}{c}\text { L3 } \\
\text { matched } \\
\text { with L2 on } \\
\text { LCM }\end{array}$ & $\begin{array}{c}\text { L3 matched } \\
\text { with L2 on } \\
\text { LCM \& } \\
\text { Geography }\end{array}$ & $\begin{array}{c}\text { L3 matched with } \\
\text { L2 on LCM, HPI } \\
\text { \& Size }\end{array}$ \\
\hline Intercept & $(1)$ & $(2)$ & $(3)$ & $(4)$ \\
\hline Servicing Fee & 0.0004 & 0.0004 & 0.0006 & 0.0004 \\
$(0.0410)^{* *}$ & $(0.0438)^{* *}$ & $(0.0510)^{*}$ & $(0.0012)^{* * *}$ \\
\hline Size & 0.6482 & 0.6884 & 0.6610 & 0.6484 \\
& $(0.0001)^{* * *}$ & $(0.0001)^{* * *}$ & $(0.0001)^{* * *}$ & $(0.0001)^{* * *}$ \\
\hline Level & 0.0001 & -0.0003 & 0.0001 & -0.0000 \\
& $(0.0895)^{*}$ & $(0.1854)$ & $(0.1232)$ & $(0.5644)$ \\
\hline Level ${ }^{*}$ & -0.0006 & -0.0003 & -0.0005 & -0.0001 \\
Servicing Fee & $(0.0063)^{* * *}$ & $(0.0350)^{* *}$ & $(0.0723)^{*}$ & $(0.5301)$ \\
\hline R2 & -0.2776 & -0.2705 & -0.2317 & -0.0714 \\
& $(0.1235)$ & $(0.0789)^{*}$ & $(0.0766)^{*}$ & $(0.5720)$ \\
\hline $\mathrm{N}$ & $24.00 \%$ & $13.55 \%$ & $15.97 \%$ & $29.45 \%$ \\
\hline
\end{tabular}

Notes: Table 4 reports the estimated coefficients for equation (2). Column (1) reports regression results for the full sample. Column (2) reports regression results based on subsample of L2 and L3 banks that adopt lower of costs or market reporting for their MSR assets. Column (3) reports regression results matching L2 banks with L3 banks on the lower of costs or market accounting choice and the geographic locations. Column (4) reports regression results matching L2 banks with L3 banks on the lower of costs or market accounting choice, the state-level house price index, and size.

${ }^{* * *},{ }^{* *},{ }^{*}$ indicates significance level at $1 \%, 5 \%$, and $10 \%$, respectively. Two-tailed p-values are reported in parentheses. Standard errors are clustered at bank level.

Variable definitions:

Servicing Fee is the servicing revenue generated from the MSR assets scaled by the beginning total assets. Size is the natural log of beginning total assets. Level equals 1 for level 3 MSRs and 0 for level 2 MSRs. 
Table 5: Association between the valuation multiples of the servicing fee with the persistence of servicing fee

$$
\begin{aligned}
\text { MSR }_{i, t} & =\gamma_{0}+\gamma_{1} \text { Servicing Fee }_{i, t}+\gamma_{2} \text { SIZE }_{i, t}+\gamma_{3} \text { Beta_Rank }_{i} \\
& +\gamma_{4} \text { Beta_Rank }_{i} * \text { Servicing Fee } e_{i, t}+\varepsilon_{i, t}
\end{aligned}
$$

Panel A - Comparison between Level 2 and Level 3 MSR prices

\begin{tabular}{|l|c|c|c|c|c|}
\hline & L2 & $\begin{array}{c}\text { L3 Full } \\
\text { Sample }\end{array}$ & $\begin{array}{c}\text { L3 matched } \\
\text { with L2 on } \\
\text { LCM }\end{array}$ & $\begin{array}{c}\text { L3 matched } \\
\text { with L2 on } \\
\text { LCM \& } \\
\text { Geography }\end{array}$ & $\begin{array}{c}\text { L3 matched } \\
\text { with L2 on } \\
\text { LCM, HPI \& } \\
\text { Size }\end{array}$ \\
& $(1)$ & $(2)$ & $(3)$ & $(4)$ & $(5)$ \\
\hline Intercept & 0.0013 & -0.0008 & -0.0006 & -0.0019 & -0.0026 \\
& $(0.4121)$ & $(0.5698)$ & $(0.7312)$ & $(0.4333)$ & $(0.1192)$ \\
\hline Servicing Fee & 3.5590 & 1.2450 & 1.6600 & 1.1716 & 1.4723 \\
& $(0.0001)^{* * *}$ & $(0.0956)^{*}$ & $(0.0001)^{* * *}$ & $(0.1598)$ & $(0.1740)$ \\
\hline Size & 0.0001 & 0.0001 & 0.0003 & 0.0005 & 0.0002 \\
& $(0.6064)$ & $(0.3215)$ & $(0.2527)$ & $(0.1795)$ & $(0.1653)$ \\
\hline Beta_Rank & -0.0004 & 0.0004 & 0.0003 & -0.0001 & 0.0002 \\
& $(0.1541)$ & $(0.0956)^{*}$ & $(0.1143)$ & $(0.5878)$ & $(0.2514)$ \\
\hline Beta_Rank $*$ & -0.0976 & 1.4980 & 1.4648 & 1.5958 & 1.5212 \\
Servicing Fee & $(0.8557)$ & $(0.0532)^{*}$ & $(0.0636)^{*}$ & $(0.0009)^{* * *}$ & $(0.0199)^{* *}$ \\
\hline R & & & & & \\
\hline N & $26.06 \%$ & $31.10 \%$ & $30.07 \%$ & $33.0 \%$ & $25.67 \%$ \\
\hline & 192 & 786 & 472 & 254 & 190 \\
\hline
\end{tabular}


Panel B: Association of the valuation multiple of the servicing fee with the persistence of servicing fee for L3 MSRs, split into disclosure and non-disclosure groups based on whether the bank provides information about prepayment assumptions and discount rates in their annual filings.

\begin{tabular}{|l|c|c|}
\hline & $\begin{array}{c}\text { L3 with } \\
\text { disclosure }\end{array}$ & $\begin{array}{c}\text { L3 without } \\
\text { disclosure }\end{array}$ \\
\hline Intercept & 0.0004 & -0.0017 \\
$(0.6381)$ & $(0.0001)^{* * *}$ \\
\hline Servicing Fee & 0.8432 & $\begin{array}{c}1.8715 \\
(0.0001)^{* * *}\end{array}$ \\
\hline Size & $(0.1532)$ & 0.0002 \\
& 0.0001 & $(0.1056)$ \\
\hline Beta_Rank & $(0.2156)$ & 0.0004 \\
& 0.0005 & $(0.1233)$ \\
\hline Beta_Rank * & $(0.0510)^{*}$ & 0.7764 \\
Servicing Fee & $(0.0001)^{* * *}$ & $(0.2152)$ \\
\hline $\mathrm{R}^{2}$ & & \\
\hline $\mathrm{N}$ & $42.28 \%$ & $38.56 \%$ \\
\hline
\end{tabular}

Notes: Table 5 reports the estimated coefficients for equation (3). Panel A Column (1) reports regression results for the level 2 banks. Panel A Column (2) reports regression results for all level 3 banks. Panel A Column (3) reports results for the subsample of level 3 banks that adopt lower of costs or market reporting for their MSR assets. Panel A Column (4) reports regression results for the subsample of level 3 banks that are matched with level 2 banks on the lower of costs or market accounting choice and geographic location. Panel A Column (5) reports regression results for the subsample of level 3 banks that are matched with level 2 banks on the lower of costs or market accounting choice, the state-level house price index, and size.

${ }^{* * *},{ }^{* *},{ }^{*}$ indicate significance level at $1 \%, 5 \%$, and $10 \%$, respectively. Two-tailed p-values are reported in parentheses. Standard errors are clustered at firm level.

$\boldsymbol{M S R}$ is the fair value of mortgage servicing right scaled by the beginning balance of total assets.

Servicing Fee is the servicing fee generated from the servicing assets scaled by beginning total assets. Size is the natural log of total assets. Beta_Rank is the quartile rank variable of the persistence of the servicing fee estimated for each bank following equation (2). 
Table 6: Association between the valuation multiples of the servicing fee with the refinancing risk and foreclosure risk

$M S R_{i, t}=\delta_{0}+\delta_{l}$ Servicing Fee $_{i, t}+\delta_{2}$ SIZE $_{i, t}+\delta_{3} R E F I$ RISK $K_{i, t}+\delta_{4} F_{\text {FORE_RISK }}$

$+\delta_{5} R E F I \_R I S K_{i t} *$ Servicing Fee $e_{i, t}+\delta_{6} F_{O R E \_R I S K_{i t}} *$ Servicing Fee $e_{i, t}+\varepsilon_{i, t}$

Panel A - Comparison between Level 2 and Level 3 MSR prices

\begin{tabular}{|c|c|c|c|c|c|}
\hline & $\begin{array}{l}\text { L2 } \\
\text { (1) }\end{array}$ & $\begin{array}{c}\text { L3 full } \\
\text { sample } \\
\text { (2) }\end{array}$ & $\begin{array}{c}\text { L3 matched } \\
\text { with L2 on } \\
\text { LCM } \\
\text { (3) }\end{array}$ & $\begin{array}{l}\text { L3 matched } \\
\text { with L2 on } \\
\text { LCM \& } \\
\text { Geography } \\
\text { (4) }\end{array}$ & $\begin{array}{l}\text { L3 matched } \\
\text { with L2 on } \\
\text { LCM, HPI \& } \\
\text { Size } \\
\text { (5) }\end{array}$ \\
\hline Intercept & $\begin{array}{c}0.0033 \\
(0.1499)\end{array}$ & $\begin{array}{l}-0.0007 \\
(0.5632)\end{array}$ & $\begin{array}{c}0.0009 \\
(0.3690)\end{array}$ & $\begin{array}{c}0.0039 \\
(0.0441)^{* *}\end{array}$ & $\begin{array}{c}0.0035 \\
(0.0047)^{* * *}\end{array}$ \\
\hline Servicing Fee & $\begin{array}{c}4.3538 \\
(0.0001)^{* * *}\end{array}$ & $\begin{array}{c}7.9985 \\
(0.0001)^{* * *}\end{array}$ & $\begin{array}{c}8.6919 \\
(0.0004)^{* * *}\end{array}$ & $\begin{array}{c}7.7146 \\
(0.0001)^{* * *}\end{array}$ & $\begin{array}{c}10.072 \\
(0.0018)^{* * *}\end{array}$ \\
\hline Size & $\begin{array}{l}-0.0001 \\
(0.7466)\end{array}$ & $\begin{array}{c}0.0002 \\
(0.2412)\end{array}$ & $\begin{array}{c}0.0002 \\
(0.2100)\end{array}$ & $\begin{array}{c}0.0001 \\
(0.7813)\end{array}$ & $\begin{array}{c}0.0001 \\
(0.8417)\end{array}$ \\
\hline REFI_RISK & $\begin{array}{l}-0.0034 \\
(0.2889)\end{array}$ & $\begin{array}{l}-0.0050 \\
(0.1329)\end{array}$ & $\begin{array}{l}-0.0035 \\
(0.2050)\end{array}$ & $\begin{array}{l}-0.0061 \\
(0.0912)^{*}\end{array}$ & $\begin{array}{l}-0.0050 \\
(0.1211)\end{array}$ \\
\hline FORE_RISK & $\begin{array}{l}-0.0049 \\
(0.5536)\end{array}$ & $\begin{array}{c}0.0144 \\
(0.3348)\end{array}$ & $\begin{array}{c}0.0106 \\
(0.4236)\end{array}$ & $\begin{array}{c}0.0272 \\
(0.1025)\end{array}$ & $\begin{array}{c}0.0212 \\
(0.2516)\end{array}$ \\
\hline $\begin{array}{l}\text { REFI_RISK * } \\
\text { Servicing Fee }\end{array}$ & $\begin{array}{c}-2.0351 \\
(0.6384)\end{array}$ & $\begin{array}{c}-11.65 \\
(0.0245)^{* *}\end{array}$ & $\begin{array}{c}-13.57 \\
(0.0289)^{* *}\end{array}$ & $\begin{array}{c}-9.01 \\
(0.0415)^{* *}\end{array}$ & $\begin{array}{c}-10.34 \\
(0.0325)^{* *}\end{array}$ \\
\hline $\begin{array}{l}\text { FORE_RISK * } \\
\text { Servicing Fee }\end{array}$ & $\begin{array}{c}-30.69 \\
(0.5028)\end{array}$ & $\begin{array}{c}-91.58 \\
(0.0365)^{* *}\end{array}$ & $\begin{array}{c}-75.09 \\
(0.0966)^{*}\end{array}$ & $\begin{array}{c}-100.81 \\
(0.0235)^{* *}\end{array}$ & $\begin{array}{c}-104.51 \\
(0.0158)^{* *}\end{array}$ \\
\hline $\mathrm{R}^{2}$ & $22.93 \%$ & $35.55 \%$ & $34.72 \%$ & $37.95 \%$ & $36.04 \%$ \\
\hline $\mathrm{N}$ & 192 & 786 & 472 & 254 & 190 \\
\hline
\end{tabular}


Panel B: Comparison between Level 3 MSR prices with disclosures and Level 3 MSR prices without disclosures

\begin{tabular}{|l|c|c|}
\hline & $\begin{array}{c}\text { L3 with } \\
\text { disclosure }\end{array}$ & $\begin{array}{c}\text { L3 without } \\
\text { disclosure }\end{array}$ \\
\hline Intercept & $\begin{array}{c}-0.0035 \\
(0.0085)^{* * *}\end{array}$ & $\begin{array}{c}0.0018 \\
(0.0368)^{* *}\end{array}$ \\
\hline Servicing Fee & $\begin{array}{c}10.561 \\
(0.0001)^{* * *}\end{array}$ & $\begin{array}{c}5.5891 \\
(0.0001)^{* * *}\end{array}$ \\
\hline Size & 0.0002 & 0.0001 \\
& $(0.1989)$ & $(0.5234)$ \\
\hline REFI_RISK & -0.0058 & -0.0024 \\
& $(0.0985)^{*}$ & $(0.3654)$ \\
\hline FORE_RISK & 0.0235 & -0.0125 \\
& $(0.2254)$ & $(0.5698)$ \\
\hline REFI_RISK * & -15.69 & -4.489 \\
Servicing Fee & $(0.0289)^{* *}$ & $(0.6184)$ \\
\hline FORE_RISK $*$ & -110.09 & -40.25 \\
Servicing Fee & $(0.0001)^{* * *}$ & $(0.3702)$ \\
\hline R & & \\
\hline N & $40.55 \%$ & $32.51 \%$ \\
\hline
\end{tabular}

Notes: Table 6 reports the estimated coefficients for equation (4). Panel A Column (1) reports regression results for the level 2 banks. Panel A Column (2) reports regression results for all level 3 banks. Panel A Column (3) reports results for the subsample of level 3 banks that adopt lower of costs or market reporting for their MSR assets. Panel A Column (4) reports regression results for the subsample of level 3 banks that are matched with level 2 banks on the lower of costs or market accounting choice and geographic location. Panel A Column (5) reports regression results for the subsample of level 3 banks that are matched with level 2 banks on the lower of costs or market accounting choice, the state-level house price index, and size.

${ }^{* * *, * *, *}$ indicate significance level at $1 \%, 5 \%$, and $10 \%$, respectively. Two-tailed $\mathrm{p}$-values are reported in parentheses. Standard errors are clustered at firm level.

$\boldsymbol{M S R}$ is the fair value of mortgage servicing right scaled by the beginning balance of total assets.

Servicing Fee is the servicing fee generated from the servicing assets scaled by beginning total assets. $\boldsymbol{F O R E} \_\boldsymbol{R I S K}$ is the percentage of residential mortgage serviced for others that are in process of foreclosure, measured for each bank quarter. Size is the natural log of total assets. REFI_RISK is the state-level refinancing rate, which is measured for each state-year as the amount of loans approved for refinancing purpose divided by total amount of loans approved. 